\title{
Correlation of serum acute-phase proteins with bone repair in rabbits (Oryctolagus cuniculus) submitted to partial radio ostectomy
}

\author{
Karina Calciolari ${ }^{* * 2}$ (D) Adrielly Dissenha ${ }^{2}$ Júlian Andrés Sanjuán Galíndez ${ }^{2}$ \\ Dayvid Vianêis Farias de Lucena ${ }^{2}$ Pedro Paulo Rossignoli \\ Fabiana Del Lama Rocha ${ }^{2}$ Bruno Watanabe Minto ${ }^{2}$ (D)
}

${ }^{1}$ Programa de Pós-graduação em Cirurgia Veterinária, Universidade Estadual Paulista Júlio de Mesquita Filho (UNESP), Jaboticabal, SP, Brasil. E-mail: karinaveterinaria@yahoo.com. ${ }^{*}$ Corresponding author.

${ }^{2}$ Departamento de Clínica e Cirurgia Veterinária, Universidade Estadual Paulista Júlio de Mesquita Filho (UNESP), Jaboticabal, SP, Brasil.

\begin{abstract}
Bone trauma triggers an acute inflammatory response, which can alter the serum concentration of acute-phase proteins (PFA). We aimed to evaluate the effectiveness of PFA measurement as a laboratory biomarker for inflammation related to bone regeneration. A partial ostectomy of the right radius was performed on 22 young male rabbits. The complete blood count, albumin, ceruloplasmin, haptoglobin, $C$-reactive protein, and transferrin levels were recorded and correlated with the radiographic evolution of bone healing. Statistically the best correlations with the inflammatory process and radiological findings were reported with haptoglobin and transferrin compared to the other measured PFAs. Haptoglobin and transferrin showed a maximum peak 24 and 36 hours after surgery, respectively. Transferrin displayed signs of decrease in the first 6 hours after surgery, in advance of the leukocyte response. The measurement of acute-phase proteins proved to be viable, considering the conditions in which the present study was carried out. Among all variables studied, haptoglobin and transferrin showed best correlation with the inflammatory process of bone healing. Additional studies are needed to determine the sensitivity of acute-phase proteins as predictors of complications in the treatment of fractures.
\end{abstract}

Correlação do proteinograma sérico com a reparação óssea em coelhos (Oryctolagus cuniculus) submetidos à ostectomia parcial do rádio

RESUMO: Os traumas ósseos desencadeiam resposta inflamatória aguda e consequentemente alteram a concentração sérica das proteínas de fase aguda (PFA), podendo essas representarem um parâmetro para avaliação da evolução do processo inflamatório relacionado à cicatrização óssea, assim como complicações. Objetivou-se avaliar a inter-relação da mensuração de PFAs com a repação óssea em coelhos submetidos à ostectomia parcial do rádio. Foram utilizados 22 coelhos, machos, jovens (160 a 180 dias) e peso médio (3,8 $\pm 0,3)$. Para acompanhamento da evolução do processo inflamatório foram realizados hemograma completo e mensuração de albumina, ceruloplasmina, haptoglobina, proteina C reativa e transferrina, além do acompanhamento radiológico. Foi observado a melhor correlação da haptoglobina e da transferrina junto ao processo inflamatório e achados radiológicos frente às demais PFAs mensuradas. A haptoglobina apresentou pico máximo 24 horas do pós-operatório e a transferrina após 36 horas, entretanto, essa última já mostrou indícios de diminuição nas primeiras 6 horas do pós-cirúrgico, antecipadamente à resposta leucocitária. Nas condições em que o presente estudo foi realizado, a mensuração das proteinas de fase aguda mostrou-se factivel. Das proteínas estudadas, a haptoglobina e transferrina foram as que mostraram maior correlação com o processo inflamatório da cicatrização óssea. Estudos adicionais são necessários para determinar a sensibilidade das proteínas de fase aguda como previsores de complicações do tratamento das fraturas.

Palavras-chave: cicatrização, biomarcador, fraturas ósseas, inflamação, proteína de fase aguda.

\section{INTRODUCTION}

Physical injury and bone regeneration have been widely studied so as to improve the treatment of fractures and other bone disorders (MARSELL \& EINHORN, 2011). Despite the established need to investigate implants and new techniques to improve bone healing capacity, researchers around the world have been looking for ways to standardize markers capable of predicting complications in the treatment of orthopedic conditions. Currently, early clinical and radiographic signs are used to identify potential complications. However, in most cases, the process is already established. Although, a complete blood count is considered to be the reference standard for postoperative follow-up, there is a need for biomarkers that can anticipate the development of complications, allowing for earlier intervention and better results (GOVAERT et al., 2020).

Bone repair involves an inflammatory process with the intense action of pro-inflammatory cytokines, growth factors, and angiogenic factors 
released by platelets, macrophages, neutrophils, lymphocytes, and mesenchymal cells present in the primary fracture hematoma (PENG et al., 2005; GERSTENFELD et al., 2006). These proinflammatory factors also act on specific proteins, called acute-phase proteins (PFA), which guide the development of the inflammatory process (CRUVINEL et al., 2010; ECKERSALL \& SCHMIDT, 2014).

PFA can be classified as positive or negative when their serum concentration increases or decreases, respectively, in the face of homeostasis disorders (CERÓN et al., 2005; MARNELL et al., 2005). Each species has a specific type of PFA, which has a concentration between 100 and 1000 times greater in the face of an inflammatory process and is called major PFA. This hampers a comparative analysis being conducted between species (KJELGAARD-HANSEN \& JACOBSEN, 2011; CÉRON et al., 2017).

PFA have proven to be useful in monitoring pathological conditions, favoring the early identification of subclinical stages of the disease. In a study with dogs that were experimentally inoculated with Leishmania ssp., they tended to show an early serum response compared to the leukocyte peak (KJELGAARD-HANSEN \& JACOBSEN, 2011; OOHASHI et al., 2019). In this study, a significant increase in PFA was found two months before the animals showed clinical signs (MARTINEZ-SUBIELA et al., 2014). Additionally, the analysis of PFA has yielded promising results in autoimmune disorders in calves (BEZUIDENHOUT \& PRETORIUS, 2020), infectious diseases in cats and dogs (PALTRINIERI et al., 2007; KOCATURK et al., 2010), parasitic diseases in rabbits and dogs (FREITAS, 2011; MYLONAKIS et al., 2012; CÉRON et al. 2018) and tumoral diseases in cats (SELTING et al., 2000). However, the correlation between these proteins and trauma is not yet fully understood (CHRISTENSEN et al., 2015).

Recently, GOVAERT et al. (2020) reported that there are a small number of studies that correlate accurate biomarkers with the diagnosis of bone repair complications, emphasizing the need for validation as to the type and value of the analyzed parameters.

Thus, this study aimed to measure the serum concentration of albumin, ceruloplasmin, haptoglobin, c-reactive protein, and transferrin, and to verify the applicability of these PFA as laboratory parameters (biomarkers) for monitoring inflammation associated with bone repair in rabbits.

\section{MATERIALS AND METHODS}

Twenty-two healthy New Zealand White breed male rabbits (Oryctolagus cuniculus), aged 160 to 180 days, weighing $3.8 \mathrm{Kg}( \pm 0.3)$, were used. The leporids were kept in individual cages, dewormed with 15.0 milligrams per kilo $(\mathrm{mg} / \mathrm{Kg})$ oral solution of toltrazuril, and fed with commercial feed, Tifton hay (Cynodon spp.), and water ad libitum. This research was approved by the ethics committee on the use of animals of the Faculty of Agricultural and Veterinary Sciences, UNESP Jaboticabal campus, Brazil, under protocol number 019155/17.

For the surgical procedure, rabbits were pre-medicated with meperidine at a dose of $5.0 \mathrm{mg} / \mathrm{Kg}$ intramuscularly (IM) and induced with $3 \mathrm{~V} \%$ isoflurane using a face mask and subsequent orotracheal intubation. Animals were positioned in the right lateral decubitus position and had the right thoracic limb prepared for aseptic surgery (chlorhexidine 2\% and $0.5 \%$ ). A $2.5 \mathrm{~cm}$ skin incision was made in the craniomedial region of the radius and divulsion of the adjacent musculature, to enable visualization of the proximal, middle shaft of the right radius. A partial radius ostectomy $1 \mathrm{~cm}$ long was performed using an oscillatory saw. The fragment was removed along with its periosteum, forming bone failure. Soft tissue was sutured in a simple pattern separated with nylon thread (4-0). Postoperatively (PO), the rabbits were administered enrofloxacin $(5.0 \mathrm{mg} / \mathrm{Kg}$ subcutaneous, once a day per 7 days), morphine $(2.0 \mathrm{mg} / \mathrm{Kg}$, IM, after 4 hours PO), and tramadol hydrochloride (5.0 $\mathrm{mg} / \mathrm{kg}$ subcutaneous, twice a day by 3 days and once a day for 2 days).

The right thoracic limb of the animals was evaluated radiologically in craniocaudal and mediolateral positions immediately after surgery and at 15-day intervals (M15d, M30d, and M45d). The radiographic characteristics were quantified from 1 to 4 in relation to the percentage of bone callus formation (adapted from FRANCO, 2017) by two blinded evaluators. Score 1, 2, 3 and 4 were characterized by 0 to $25 \%, 5 \%$ to $50 \%, 50$ to $75 \%$, and 75 to $100 \%$, of bone failure filled with bone callus, respectively.

Three milliliters $(\mathrm{mL})$ of blood were collected from the external jugular vein, in sterile tubes, with and without ethylenediaminetetraacetic acid (EDTA), at predetermined time points (M): preoperative (M0), and 6, 24, and $36 \mathrm{~h}$ (M6h, M24h, and M36h), as well as 7, 15, 21, 30, and 45 days (M7d, M15d, M21d, M30d, and M45d) postoperative. Blood counts were processed using a veterinary hematology analyzer, and the differential leukocyte count was 
analyzed under optical microscopy. The serum was obtained by centrifuging tubes without EDTA at 5,000 revolutions per minute ( $\mathrm{rpm}$ ) for five min. The total protein was measured with a semiautomatic spectrophotometer and the serum proteinogram by the polyacrylamide gel electrophoresis method.

The hemogram and proteinogram were analyzed using the Tukey test. The radiographic analysis was analyzed using the Kruskal-Wallis test. A p-value of $<0.05$ was considered to be statistically significant. These analyzes were performed by the computer program R CORE TEAM.

\section{RESULTS AND DISCUSSION}

Fifteen days postoperatively (M15d), only $28 \%$ of the animals had evolved to score 2 on the radiographic evaluation, which was not statistically significant compared to their initial score (M0). This is consistent with the inflammatory phase and the beginning of the formation of cartilaginous callus (RAHN, 2002). At 30 days (M30d), 54\% of the rabbits had a score of $2,36 \%$ had a score of 3 , and $10 \%$ had a score of 4 . These results were significantly different $(\mathrm{P} \leq 0.05)$ between M0 and M15d. Finally, at 45 days, a higher percentage of scores 3 and 4 were observed. However, there was no statistical difference $(\mathrm{P} \leq 0.05)$ with $\mathrm{M} 30 \mathrm{~d}$, despite differences $(\mathrm{P} \leq 0.05)$ between the M0 and M15d. At M45d, bone nonunion was clinically established in $80 \%$ of the animals, characterizing the complication of fracture management (METSEMAKERS et al., 2018).
The albumin averages (Table 1) displayed slight variations at each time period, with a numerical decrease between M24h and M36h. However, this was not statistically significant. TOTHOVA et al. (2019b) obtained similar results in an experimental procedure performed with a failure in the articular cartilage and trochlear portion of the femur in sheep, where the lowest numerical concentration was 15 days postoperatively. Having kept the different inflammatory stimuli, BOZUKLUHAN et al.(2018) also reported no statistical difference between healthy cows with different degrees of endometritis. MYLONAKIS et al. (2012) obtained stable albumin values, while $\mathrm{C}$-reative protein $(\mathrm{pCR})$ and haptoglobin were altered in dogs with inflammatory complications triggered by an E. canis infection. Even so, HÜBNER et al. (2016) reported a drop in albumin in abdominal procedures in humans in the immediate postoperative period. Therefore, we believed that our results showed that there were no significant inflammatory complications to alter the concentrations of albumin, in agreement with MYLONAKIS et al. (2012), BOZUKLUHAN et al. (2018), and TOTHOVA et al. (2019b).

A peak of haptoglobin was observed at M24h (Table 1), which was up to 2 times greater and statistically different $(\mathrm{P} \leq 0.05)$ from $\mathrm{M} 0$. CÉRON et al. (2017) reported that proteins that increased 2 to 4 times after a stimulus were moderate, as observed in this study. These findings are similar to those by TOTHOVA et al. (2019a) in pigs and TOTHOVA et al. (2019b) in sheep, where an increase

Table 1 - Mean values followed by the standard deviation of the mean $( \pm)$ of the acute phase proteins: C-reactive protein $\left(\mathrm{mg} / \mathrm{dL} \mathrm{x} 10^{-1}\right)$, ceruloplasmin $\left(\mathrm{mg} / \mathrm{dL} \times 10^{-1}\right)$, haptoglobin $(\mathrm{mg} / \mathrm{dL})$, albumin $(\mathrm{mg} / \mathrm{dL})$, and transferrin $(\mathrm{mg} / \mathrm{dL})$ measured in the serum of rabbits submitted to a partial ostectomy of the right radial bone, at the following time points (M): preoperative (M0), and 6, 24, and $36 \mathrm{~h}$ (M6h, M24h and M36h), as well as 7, 15, 21, 30, and 45 days postoperative (M7d, M15d, M21d, M30d, and M45d).

\begin{tabular}{|c|c|c|c|c|c|}
\hline M & C-reactive protein & Ceruloplasmin & Albumin & Haptoglobin & Transferrin \\
\hline M0 & $0.018 \pm 0.007 \mathrm{ab}$ & $0.175 \pm 0.06 \mathrm{a}$ & $3.635 \pm 0.08 \mathrm{ab}$ & $0.168 \pm 0.13$ bcde & $0.372 \pm 0.09 \mathrm{a}$ \\
\hline M6h & $0.009 \pm 0.003 c$ & $0.154 \pm 0.06 \mathrm{ab}$ & $3.733 \pm 0.04 \mathrm{ab}$ & $0.165 \pm 0.04 \mathrm{bcde}$ & $0.342 \pm 0.02 \mathrm{ab}$ \\
\hline M24h & $0.009 \pm 0.002 c$ & $0.186 \pm 0.05 \mathrm{a}$ & $3.445 \pm 0.04 b c$ & $0.375 \pm 0.09 \mathrm{a}$ & $0.332 \pm 0.03 \mathrm{abc}$ \\
\hline M36h & $0.009 \pm 0.003 c$ & $0.163 \pm 0.05 \mathrm{ab}$ & $3.549 \pm 0.03 \mathrm{abc}$ & $0.210 \pm 0.08 \mathrm{abcd}$ & $0.297 \pm 0.03 b c$ \\
\hline M7d & $0.013 \pm 0.005 \mathrm{abc}$ & $0.127 \pm 0.03 \mathrm{ab}$ & $4.070 \pm 0.04 \mathrm{a}$ & $0.138 \pm 0.05 \mathrm{cde}$ & $0.346 \pm 0.10 \mathrm{ab}$ \\
\hline M15d & $0.012 \pm 0.004 b c$ & $0.100 \pm 0.03 b$ & $3.770 \pm 0.04 \mathrm{ab}$ & $0.324 \pm 0.22 \mathrm{ab}$ & $0.337 \pm 0.05 \mathrm{ab}$ \\
\hline M21d & $0.010 \pm 0.004 \mathrm{c}$ & $0.095 \pm 0.03 b$ & $3.659 \pm 0.05 \mathrm{ab}$ & $0.279 \pm 0.25 \mathrm{abc}$ & $0.321 \pm 0.05 \mathrm{ab}$ \\
\hline M30d & $0.011 \pm 0.004 \mathrm{c}$ & $0.170 \pm 0.07 \mathrm{ab}$ & $3.032 \pm 0.06 \mathrm{~cd}$ & $0.090 \pm 0.10 \mathrm{de}$ & $0.252 \pm 0.04 \mathrm{~cd}$ \\
\hline M45d & $0.019 \pm 0.005 a$ & $0.131 \pm 0.03 \mathrm{ab}$ & $2.750 \pm 0.04 d$ & $0.070 \pm 0.01 \mathrm{e}$ & $0.213 \pm 0.07 \mathrm{~d}$ \\
\hline
\end{tabular}


in haptoglobin concentration was observed 7 days after an experimental failure in the articular cartilage and portion of the femoral trochlea. This restored to baseline values after 14 days and was lower after 30 days. In addition, the inflammatory process directly related to surgery, anesthesia, and animal handling can be stressful, leading to an increase in cortisol (MURATA et al., 2004; TRALL, 2007) and, consequently, haptoglobin (CALDIN et al., 2009; BUSK et al., 2010). These data may justify minor but recurring peaks in M15d and M21d, in addition to those observed in the immediate post-surgical period (M24h). In M45d, it is possible to suggest that the animals were more adapted to handling since the values of this PFA were lower.

According to MEYES (1995) and BUSH (2004), it is possible to observe changes in the leukogram that suggest stressful episodes such as lymphopenia, which was observed at $6 \mathrm{~h}$ and M24h, is related to the maximum haptoglobin peak in M24h (Figure 1). Interestingly, the peak at M24hrs preceded the increase in the concentration of neutrophils, suggesting that this PFA can potentially anticipate an inflammatory process. The same was suggested by GEORGIEV et al. (2009) and CÉRON et al. (2014). Even though the lymphocytes do not suggest any type of stress linked to the second haptoglobin peak (M15d) it is possible to observe in figure 2 that the segmented neutrophils count had a small numerical increase.
Table 1 shows higher $\mathrm{pCR}(\mathrm{P} \leq 0.05)$ at $\mathrm{M} 0$ than any subsequent time periods up to M30d. A study in dogs (CHRISTENSEN et al., 2015; SCHMIDT et al., 2018) and rabbits (OOHASHI et al., 2019) observed an increase in the serum concentration of $\mathrm{pCR}$ related to morbid processes, with a peak between 24 and 48 hours. These values returned close to baseline after 7 days, which leads us to believe that the pCR peak could have occurred between M36h and $\mathrm{M} 7 \mathrm{~d}$, but was not identified.

CERÓN et al. (2018) described a dosedependent connection of pCR concentration to complex inflammatory processes, such as septic or autoimmune processes, where low values are observed in small intestinal, dermal inflammation, or diseases of viral origin and, to a greater extent, in sepsis, metastasis, and autoimmune diseases. FRANSSON et al. (2007), for example, observed lower concentrations of pCR in dogs with an aseptic uterine inflammation (mucometra) than in those with pyometra. Once again, such findings confirmed that the $\mathrm{pCR}$ values were not elevated in the present study due to the lack of significant post-surgical complications. In addition, CÉRON et al. (2014) correlated low pCR values and high haptoglobin to situations that cause an increase in serum cortisol, as occurs in stressful events. This could also justify the lower pCR values at M6h and M36h compared to baseline.

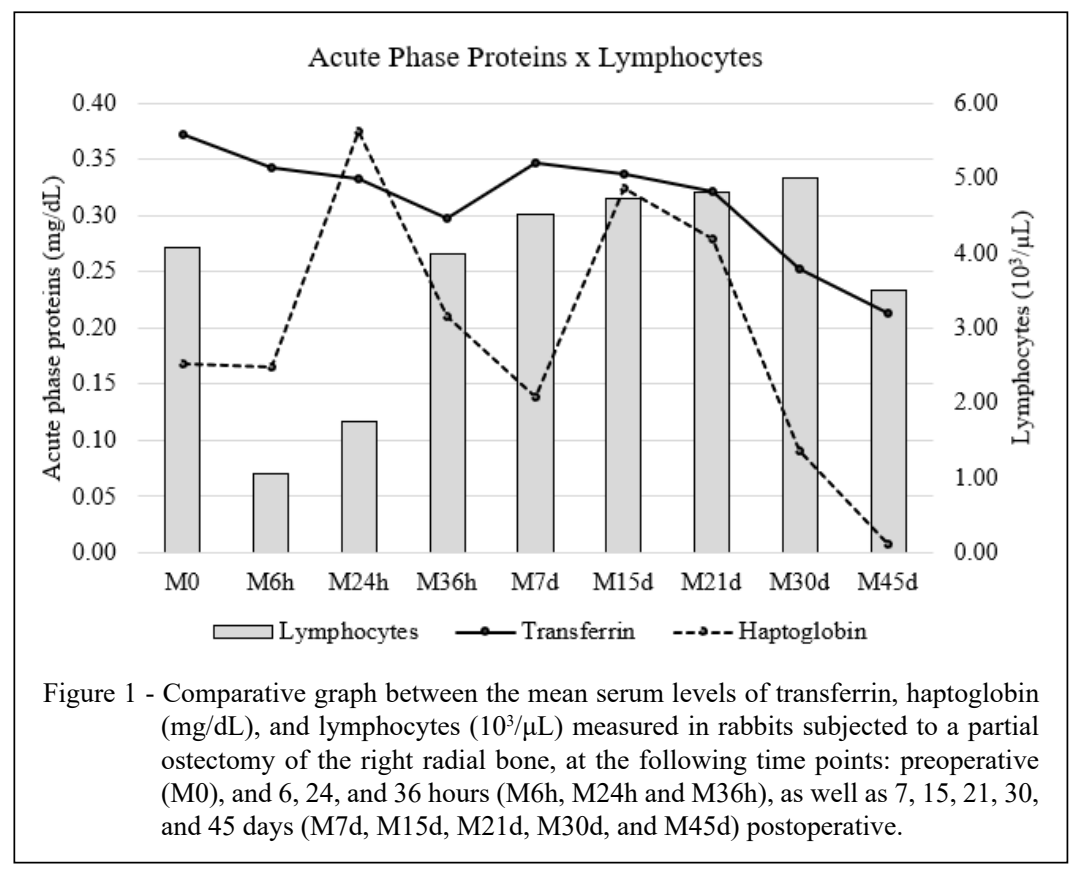

Ciência Rural, v.51, n.2, 2021. 


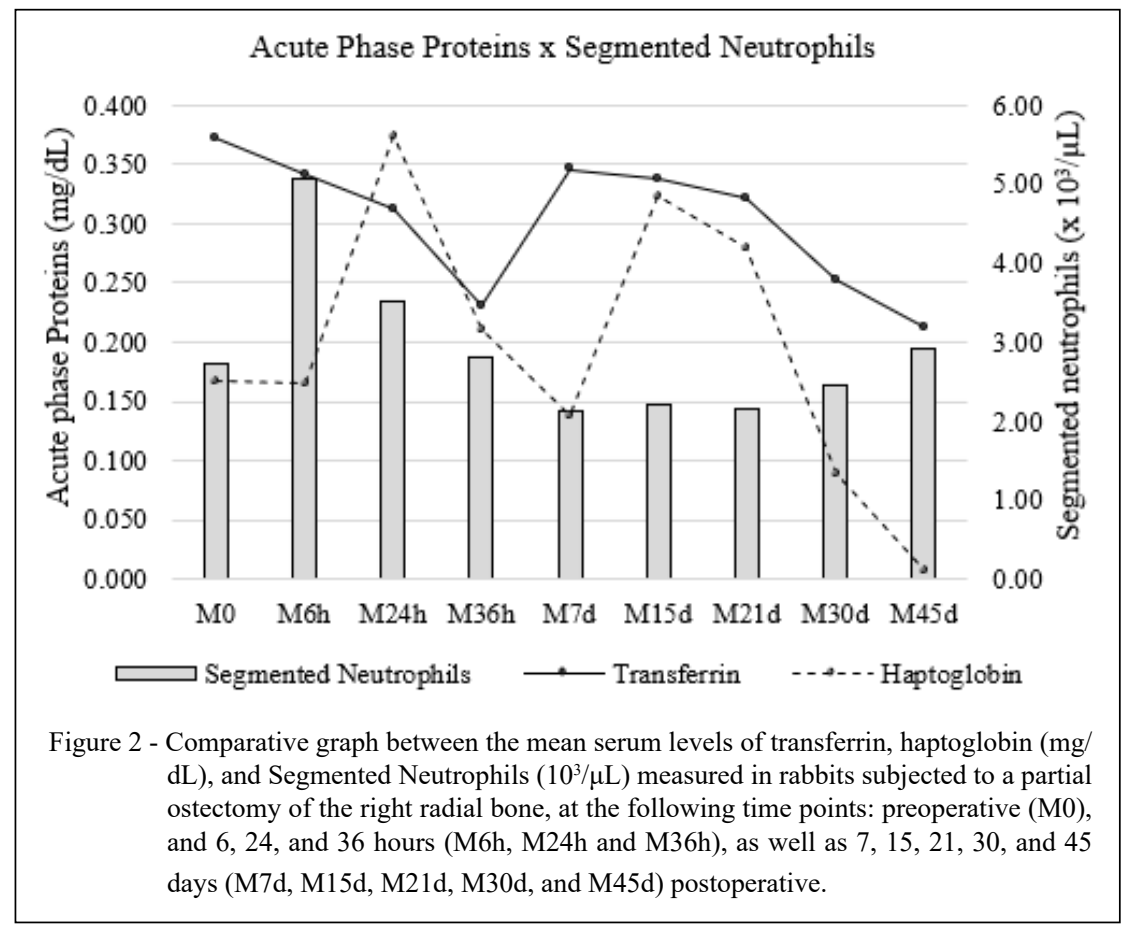

Higher concentrations of ceruloplasmin were identified at M24h. However, the mean values were not significantly different $(\mathrm{P} \leq 0.05)$ from $\mathrm{M} 0$. At M15d and M21d, the values were smaller and statistically different from M0 $(\mathrm{P} \leq 0.05)$ (Table 1$)$. Following the same response pattern discussed earlier, there is an increase in this PFA in more severe inflammatory clinical conditions, followed by a reduction after 7 days (KAYA et al., 2016; BOZUKLUHAN et al., 2018). FREITAS et al. (2011) identified a gradual increase in ceruloplasmin in rabbits infected with Eimeria stiedai. The values obtained were dose-dependent on the evolution of the inflammatory process. GEORGIEVA et al. (2009) observed a subtle increase in ceruloplasmin in rabbits that were experimentally inoculated with $E$. coli compared to the haptoglobin values, which were up to 10 times higher. It was deducted that the magnitude of the inflammatory process generated by the surgical procedure, as well as the complications related to bone nonunion, were not sufficient to determine the response pattern of serum ceruloplasmin in the species used.

Transferrin decreased from the first time point evaluated, reaching a negative peak at M36h, which was significantly different $(\mathrm{P} \leq 0.05)$ from $\mathrm{M} 0$. At $\mathrm{M} 36 \mathrm{~h}$, a significant negative transferrin peak $(\mathrm{P} \leq 0.05)$ was observed. In addition, hemoglobin values at M36h and M7d were significantly $(\mathrm{P} \leq 0.05)$ lower than those at M6h. ULUTAS et al. (2005) described an association between anemia and a decrease in haptoglobin and transferrin. This suggested these blood collections in a short time between M0 and M36h may have influenced the hemoglobin values and, consequently, the PFA mentioned above. Even so, a haptoglobin peak at M24h followed by a leukocyte increase (Figure 2) demonstrates that there was already an inflammatory process responsible for the serum alteration of PFA and that it could have been greater had there not been a significant drop in hemoglobin. A comparative analysis of the inflammatory profile from a leukometric point of view and PFA in figure 2 reveals that transferrin is responsive to inflammation as early as M6h. At this time, NS are sequestered to the inflammatory focus and display a decrease in serum concentration as described by SWENSON and REECE (1996). These findings are consistent with the statements by MURATA et al. (2004), PALTRINIERI (2007), and CÉRON et al. (2017) that PFA can anticipate the diagnosis of inflammatory conditions even when they are still subclinical.

\section{CONCLUSION}

The measurement of acute-phase proteins proved to be viable, considering the conditions in 
which the present study was carried out. Among all variables studied, haptoglobin and transferrin showed best correlation with the inflammatory process of bone healing. Additional studies are needed to determine the sensitivity of acute-phase proteins as predictors of complications in fractures treatment.

\section{ACKNOWLEDGEMENTS}

This research was funded by Conselho Nacional de Desenvolvimento Científico e Tecnológico $(\mathrm{CNPq}$ - number 141099 / 2016-0).

\section{ETHICS AND BIOSAFETY COMMITTEE}

Protocol 019155/17

\section{DECLARATION OF CONFLICTS OF INTERESTS}

The authors declare no conflicts of interest. The founding sponsors had no role in the development of the study; in the collection, analysis, or interpretation of data; in the writing of the manuscript and in the decision to publish the results.

\section{AUTHORS' CONTRIBUTIONS}

The authors contributed equally to the manuscript.

\section{REFERENCES}

BEZUIDENHOUT, J. A. et al. The central role of acute phase proteins in rheumatoid arthritis: involvement in disease autoimmunity, inflammatory responses, and the heightened risk of cardiovascular disease. Seminars Thrombosis Hemostasis, v.46, p.465-483, 2020. Available from: <https://www.thieme-connect. com/products/ejournals/pdf/10.1055/s-0040-1709475.pdf $>$. Accessed: Jun. 11, 2020. doi: 10.1055/s-0040-1709475.

BOZUKLUHAN, K. et al. Investigation of haptoglobin, serum amyloid A, and some biochemical parameters in calves with omphalitis, Veterinary World, v.11, n.8, p.1055-1058, 2018. Available from: <https://www.ncbi.nlm.nih.gov/pmc/articles/ PMC6141279/pdf/VetWorld-11-1055.pdf>. Accessed: Jun. 11, 2020. doi: 10.14202/ vetworld.2018.1055-1058.

BUSK, $P$. et al. Administration of perioperative penicillin reduces postoperative serum amyloid A response in horses being castrated standing. Veterinary Surgery, v.39, n.5, p.638-643, 2010. Available from: <https://onlinelibrary.wiley.com/doi/ epdf/10.1111/j.1532-950X.2010.00704.x>. Accessed: Jun. 11, 2020. doi:10.1111/j.1532-950X.2010.00704.x.

CALDIN, M. et al. "Serum acute phase protein concentrations in dogs with hyperadrenocorticism with and without concurrent inflammatory conditions." Veterinary clinical Pathology, v.38, n.1, p.63-68, 2009. Available from: <https://onlinelibrary.wiley. com/doi/abs/10.1111/j.1939-165X.2008.00087.x>. Accessed: Jun. 11, 2020. doi:10.1111/j.1939-165X.2008.00087.x.

CERÓN, J. Acute phase proteins in dogs and cats: Current knowledge and future perspectives. Veterinary Clinical
Pathology, v.34, n.2, p.85-99, 2005. Available from: <https:// onlinelibrary.wiley.com/doi/abs/10.1111/j.1939-165X.2005. tb00019.x sid $=$ nlm $\% 3^{\mathrm{a}}$ pubmed\&>. Accessed: Sep. 20, 2019. doi: 10.1111/j.1939-165X.2005.tb00019.x.

CERÓN, J. et al. Use of acute phase proteins for the clinical assessment and management of canine leishmaniosis: general recommendations. BMC Vet Res, v.14. n.1. p.1-5, 2018. Available from: <https:/www.ncbi.nlm.nih.gov/pmc/articles/PMC6011270/ pdf/12917_2018_Article_1524.pdf $>$. Accessed: Jun. 11, 2020. doi: 10.1186/s $1 \overline{2} 917-\overline{0} 18-1524-y$.

CHRISTENSEN, M. B. et al. C-reactive protein: quantitative marker of surgical trauma and post-surgical complications in dogs: a systematic review. Acta Veterinária Scandinavica, v. 57. n.71, 2015. Available from: <https://www.ncbi.nlm.nih.gov/ pmc/articles/PMC4615867/pdf/13028 2015 Article 164.pdf>. Accessed: Jun. 11, 2020. doi: 10.1186/s13028-015-0164-5.

CRUVINEL, W. et al. Fundamentos da imunidade inata com ênfase nos mecanismos moleculares e celulares da resposta inflamatória. Revista Brasileira Reumatologia, v.50, p.4, p.434-461, 2010. Available from: $<$ http://www.scielo.br/scielo.php?script=sci arttext \&pid=S0482-50042010000400008>. Accessed: Sep. 20 2019. doi: 10.1590/S0482-50042010000400008.

ECKERSALL, P. D; SCHMIDT, S. The final hurdles for acute phase protein analysis in small animal practice. J Small Anim Pract, v.55. p.1-3, 2014. Available from: <https://onlinelibrary. wiley.com/doi/epdf/10.1111/jsap.12168>. Accessed: Jun. 11, 2020. doi: 10.1111 jsap. 12168 .

FRANCO, G.G. Células-tronco mesenquimais autólogas derivadas e tecido adiposo, associadas ou não à hidroxiapatita, na regeneração de defeito ósseo em rádio de coelhos (Oryctolagus cuniculus). 2017. Thesis ( $\mathrm{PhD}$ in Veterinary Surgery) - Course of Veterinary Medicine of Faculty of Veterinary Agricultural Sciences, UNESP.

FRANSSON, B. et al. "Assessment of three automated assays for C-reactive protein determination in dogs." American journal of veterinary research, v.68. n. 12. p.1281-1286, 2007. Available from: <https://pubmed.ncbi.nlm.nih.gov/18052731/>. Accessed: Jun. 11, 2020. doi:10.2460/ajvr.68.12.1281.

FREITAS, F. L.C. et al. Systemic inflammatory response indicators in rabbits (Oryctolagus cuniculus) experimentally infected with sporulated oocysts of Eimeria stiedai (Apicomplexa: Eimeriidae). Revista Brasileira Parasitologia Veterinária (Online), v.20, n.2, p.121-126, 2011. Available from: <http://www. scielo.br/scielo.php?script=sci_arttext\&pid=S1984296120110002 $00006 \& \operatorname{lng}=$ pt\&nrm=iso $>$. Accessed: Sep. 20, 2019. doi: 10.1590/ S1984-29612011000200006.

GERSTENFELD, L.C. Three-dimensional reconstruction of fracture callus morphogenesis. Journal of Histochemistry and Cytochemistry, v.54, p.1215-1228, 2006. Available from: $<$ https://journals.sagepub.com/doi/full/10.1369/jhc.6A6959.200 6? urlver $=$ Z39.882003\&rfr_id $=$ ori\%3Arid\%3Acrossref.org\&rfr_ dat $=$ cr_pub\%3Dpubmed $>$. Accessed: Sep. 20, 2019. doi:10.1369/ jhc.6A6959.2006.

GOVAERT, G.A.M. et al. Diagnosing fracture-related infection: current concepts and recommendations. Journal Orthopaedic Trauma. v.34, n.1, p.8-17, 2020. Available from: <https://www. ncbi.nlm.nih.gov/pmc/articles/PMC6903359/pdf/jot-34-08.pdf >. Accessed: Jun. 11, 2020. doi:10.1097/BOT.0000000000001614. 
HÜBNER, M. et al. Postoperative albumin drop is a marker for surgical stress and a predictor for clinical outcome: a pilot study. Gastroenterology research and practice, v.2016, p.1-8. 2016. Available from: $<$ https://www.ncbi.nlm.nih.gov/pmc/articles /PMC4736779/pdf/GRP2016-8743187.pdf>. Accessed: Jun. 11, 2020. doi: $10.1155 / 2016 / 8743187$.

KJELGAARD-HANSEN, M; JACOBSEN, S. Assay validation and diagnostic applications of major acute-phase protein testing in companion animals. Clinical Chemistry and Laboratory Medicine, v.35, p.51-70, 2011. Available from: $\quad<$ https://www.sciencedirect.com/science/article/pii/ S0272271210001447?via\%3Dihub>. Accessed: Sep. 20, 2019. doi: 10.1016/j.cll.2010.10.002.

KOCATURK, M. Prognostic value of serum acute phase proteins in dogs with parvoviral enteritis. Journal of the Small Animal Practice, v.51, p.478-483, 2010. Available from: $\quad<$ https://onlinelibrary.wiley.com/doi/epdf/10.1111 /j.1748-5827.2010.00965.x>. Accessed: Jun. 11, 2020. doi: 0.1111/j.1748-5827.2010.00965.x.

MARNELL, L. C-reactive protein: ligands, receptors and role in inflammation. Clinical Immunology, v.117, n.2, p.104-111, 2005. Available from: <https:/www.sciencedirect.com /science/article/ abs/pii/S1521661605002809?via\%3Dihub>. Accessed: Sep. 20, 2019. doi:10.1016/j.clim.2005.08.004.

MARSELL, R.; EINHORN, T.A. The biology of fracture healing. Injury, v.42, v.6, p.551-555, 2011. Available from: $<$ https://www. injuryjournal.com/article/S0020-1383(11)00125-2/fulltext>. Accessed: Sep. 20, 2019. doi: 10.1016/j.injury.2011.03.031.

MARTINEZ-SUBIELAS, et al. Serum ferritin and paraoxonase-1 in canine leishmaniosis. Comp Immunol Microbiol Infect Dis, v.37, n.1, p.23-29, 2014. Available from: <https://www.sciencedirect. com/science/article/abs/pii/S0147957113000891?via\%3Dihub>. Accessed: Jun. 11, 2020. doi: 10.1016/j.cimid.2013.10.004.

MURATA, H. et al. Current research on acute phase proteins in veterinary diagnosis: An overview. Veterinary Journal, v.168, n.1, p.28-40, 2004. Available from: <https://www.sciencedirect. com/science/article/abs/pii/S0009898104004292?via\%3Dihub>. Accessed: Sep. 20, 2019. doi: 10.1016/j.cccn.2004.08.018.

MYLONAKIS, M. E. et al. Serum acute phase proteins in $\operatorname{dogs}$ with symptomatic esophageal spirocercosis. Veterinary
Parasitology, v.190. p.191-195, 2012. Available from: $<$ https://www.sciencedirect.com/science/article/abs/pii/ S0304401714000740?via\%3Dihub>. Accessed: Jun. 11, 2020. doi: 10.1016/j.vetpar.2014.02.001.

PALTRINIERI, S. Early biomarkers of inflammation in dogs and cats: The acute phase proteins. Veterinary Research Communications, v.31, n.1, p.125-129, 2007. Available from: $<$ https://link.springer.com/article/10.1007/s11259-007-0107-3>. Accessed: Sep. 20, 2019. doi: 10.1007/s11259-007-0107-3.

R CORE TEAM. R: A language and environment for statistical computing. R Foundation for Statistical Computing, Vienna, Austria. 2008 URL https://www.R-project.org/.

RAHN, B.A. Bone healing: histological and physiologic concepts. In: Fackelman, GE. Bone in clinical orthopedics. Thieme: Stuttgart. 2002. 287-326p.

SELTING, K. A. et al. Serum alpha 1-acid glycoprotein concentrations in healthy and tumor-bearing cats. Journal of Veterinary Internal Medicine, v.14. p.503-506, 2000. Available from: <https://onlinelibrary.wiley.com/ doi/abs/10.1111/j.1939-1676.2000.tb02267.x?sid=nlm \%3Apubmed $>$. Accessed: Jun. 11, 2020. doi: 10.1111/j.19391676.2000.tb02267.x.

TOTHOVA C, et al. Changes in the acute-phase protein concentrations and activities of some enzymes in pigs following the repair of experimentally induced articular cartilage defects using two types of biocement powder. Animals (Basel), v.9. n.11, p.931, 2019a. Available from: <https://www.ncbi.nlm.nih. gov/pmc/articles/PMC6912659/pdf/animals-09-00931.pdf. $>$. Accessed: Jun. 11, 2020. doi: 10.3390/ani9110931.

TOTHOVA, C. et al. The serum protein profile and acute phase proteins in the postoperative period in sheep after induced articular cartilage defect. Materials (Basel, Switzerland), v.12, n.1, p.142, 2019b. Available from: <https://www.ncbi.nlm.nih.gov/pmc/ articles/PMC6337335/pdf/materials-12-00142.pdf>. Accessed: Jun. 11, 2020. doi: 10.3390/ma12010142.

ULUTAS, B. et al. Serum concentration of some acute phase proteins in naturally occurring canine babesiosis: a preliminary study. Veterinary Clinical Pathology. v.34. p.144-147, 2005. Available from: <https://onlinelibrary.wiley.com/doi/abs/10.1111/ j.1939-165X.2005.tb00028.x?sid=nlm\%3Apubmed $>$. Accessed: Jun. 11, 2020. doi: 10.1111/j.1939-165x.2005.tb00028.x. 